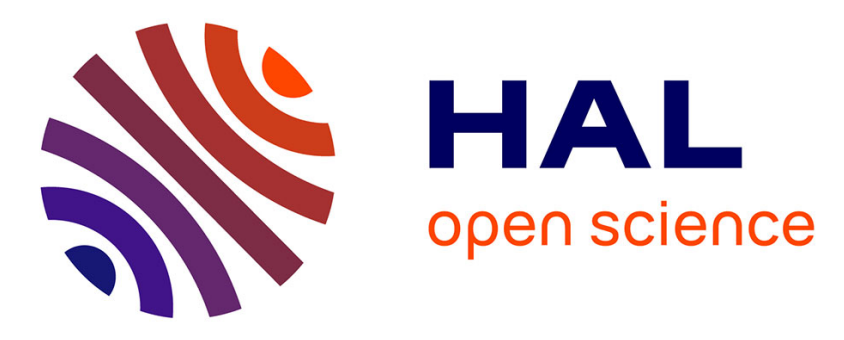

\title{
Toward a stand-alone monitoring system for mobile telephony base stations exposure using simulations and smartphones crowdsourcing
}

Nicolas Noé, François Gaudaire, Mame Diarra Bousso Lo-Ndiaye, Pierre Combeau

\section{To cite this version:}

Nicolas Noé, François Gaudaire, Mame Diarra Bousso Lo-Ndiaye, Pierre Combeau. Toward a standalone monitoring system for mobile telephony base stations exposure using simulations and smartphones crowdsourcing. First URSI Atlantic Radio Science Conference, May 2015, Gran Canaria, Canary Islands, Spain. hal-01138279

\author{
HAL Id: hal-01138279 \\ https://hal.science/hal-01138279
}

Submitted on 1 Apr 2015

HAL is a multi-disciplinary open access archive for the deposit and dissemination of scientific research documents, whether they are published or not. The documents may come from teaching and research institutions in France or abroad, or from public or private research centers.
L'archive ouverte pluridisciplinaire HAL, est destinée au dépôt et à la diffusion de documents scientifiques de niveau recherche, publiés ou non, émanant des établissements d'enseignement et de recherche français ou étrangers, des laboratoires publics ou privés. 


\title{
Toward a stand-alone monitoring system for mobile telephony base stations exposure using simulations and smartphones crowdsourcing
}

\author{
N. Noé ${ }^{(1)}$, F. Gaudaire ${ }^{(1)}$, M. Diarra Bousso Lô-Ndiaye* ${ }^{(1)}$ and P. Combeau ${ }^{(2)}$ \\ (1) Centre Scientifique et Technique du Bâtiment, division éclairage et électromagnétisme, \\ (2) XLIM Institute, UMR CNRS 7252, SIC department, Futuroscope, France
}

Monitoring of people electromagnetic waves exposure to mobile telephony base stations is of interest for local communities, in order to communicate towards inhabitants or to enforce local exposure rules. This could be achieved with measurements but they quickly become outdated due to the ever changing network. Furthermore this could be very expensive for a large number of measurement spots. On the other hand numerical simulation gives accurate results but need precise antenna description (location, power, radiation diagram, Idots). Unfortunately such precise information is not publicly available. Nevertheless nowadays most terminals are smartphones that give access to information (received signal strength, location with GPS) that allow them to be used as cheap, low-quality sensors.

In this paper we first introduce numerical simulation of electric field generated by base station antennas anywhere in urban environment, and discuss about the essential parameters do describe exposure level. Second we describe useful information for exposure that can be gathered from smartphones. As expected the collected information is sparse (signal strength from current cell only and in $2 \mathrm{G}$ cases neigboring cells) and inaccurate (low definition and saturation of the signal strength value, time lag in value change, GPS uncertainty). Nevertheless we demonstrate in an almost open area that it can be correlated very well to simulation results.
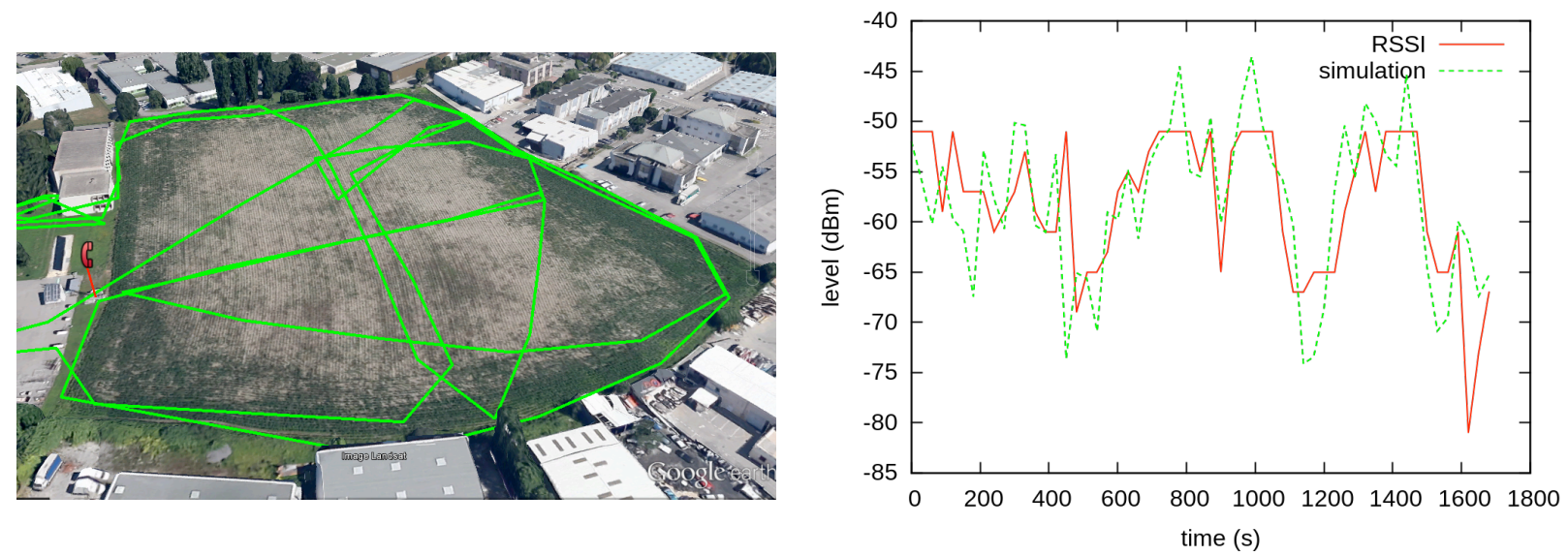

Figure 1: Comparison between phone received signal strength and simulation

Third we lay the foundation for a future autonomous monitoring system. Antenna parameters are initialized with (inaccurate) publicly available data, either from official organizations or from web databases and an initial simulation is performed. Then antenna parameters are tuned to maximize correlation with the signal strength measurements. To this day only a proof of concept with artificially generated signal strength data exists. It is expected that the mass effect of collected data through crowdsourcing will compensate the low quality of the real data. 